DOI: 10.20472/IAC.2018.042.040

LUCIE POVOLNÁ

Tomas Bata University in Zlín, Czech Republic

\title{
BUSINESS CYCLE SURVEY AND B2B BUYING DECISION
}

\begin{abstract}
:
The objective of the paper is to determine the degree of agreement between the anticipated industrial demand and the subsequent development of the indicators of economy performance, considering the time period. The methodology of the research compares the balances of business cycle indicators, to the balances of real industry performance in the machining sector. The analyzed time period was 2003 - 2017, and it was split into several parts on account of diverse economic development. It was proved that the reliability of the selected data varies in accordance with the development of economy. The results indicate that there is a dependency between the assessed variables; the more positive economic development, the more reliable the data. The research was realized in the Czech industry with the intention of providing a tool for another potential user - so far, an underestimated one - an industrial business. The results should serve as a tool for mitigation of the B2B market purchase decision uncertainty.
\end{abstract}

\section{Keywords:}

business cycle indicator, B2B buying, economic forecast

JEL Classification: E32, M31, L16 


\section{Introduction}

The manufacturing market is very dynamic; it calls for quick reactions to changes, and it increases the need for short-term instruments for the forecasting of future industrial development. The purpose of understanding the economic development is to be able to modify market strategies early enough not to lose a competitive advantage. The companies gather miscellaneous information on the microeconomic level (organizational, market, personal, societal) and on the macroeconomic level as well (Webster and Wind, 1996). Future economic development is a matter of broad research so as to find as accurate an estimate instrument as possible. Those estimates are important primarily for policy makers and financial institutions (Bruno and Lupi, 2003; Erkel-Rousse and Minodier, 2009); however, they are a part of the basic concept of the organizational situation analysis.

\subsection{Industrial market}

Mechanical engineering, in which the possibility of prediction utilisation is oriented, is a significant industry for the Czech Republic and its economy, and it also reflects its potential as the engineering products are production factors in most production processes. The Czech Republic is the twelfth most important world exporter and eighth in consumption per person (SST, 2017).

The managers of the machinery industry gain branch development information mainly at industry events and industry associations (Povolná, 2017). The industry is under the strong influence of the economic development of certain countries and even of continents. Those economies fluctuate, which makes the business cycle prediction very useful. Both expansion and recession may signify opportunities and threats. During recession the companies tend to decrease costs and the R\&D programmes (Srinivasan et al., 2011), so they risk long-term competitive technologic advantage. Frequently the companies do not believe in the economy turnover, and they act cautiously (Bachman, 2013) and make pessimistic decisions (Fialová, 2000). On the other hand, the economic downfall may contribute to streamlining production technology (Lin and Huang, 2012; Tavassoli, 2015) and, as Großler (2015) points out, the volatility provides an advantage for more efficient purchases of production facilities.

The immense technology development at the turn of the century caused a considerable empowerment of the B2B customer (Lillien, 2016; Wiersema, 2013). The B2B market purchasers are considered very pragmatic business partners (Brown et al., 2001), but they also tend to be affected by subjective factors (Lynch and de Chernatony, 2004). The traditional buying models are still valid (Wind and Thomas, 2010). 


\section{$1.2 \quad$ Economic predictions}

The subject of the recent research on the prediction of future economic development is mostly multi criteria analysis. It considers multiple circumstances, which results in more accurate prediction. The reliability of resulting indicators is influenced by numerous factors, such as the model principle itself, the time series length (Boivin and $\mathrm{Ng}, 2005$ ), or the analysed country and its structural changes (Erkel-Rousse and Minodier, 2009). The error rate is affected by the unknown parameter estimate method (Boivin and $\mathrm{Ng}, 2005$ ), and the factor and weights choice, which is always partly subjective Emmerson and Hendry, 1998; Erkel-Rousse and Minodier, 2009). Refining the models involves the utilisation of complementary parameters (Boivin and $\mathrm{Ng}, 2005$ ) and periodic updating with fresh data (Angelini et al., 2011). Basically, various prediction methods may provide various results (Erkel-Rousse and Minodier, 2009).

Simplicity has become a desirable approach of prediction models construction (Hansson, Jansson and Löf, 2004). The predictions with more explanatory variables and many estimated parameters generate more ineffective and unstable predictions than the simple ones, despite significant volatilities (Hansson et al., 2004; Clark and West 2007). The short-term macroeconomic analysis demand is rising (Hansson, Jansson and Löf, 2004) partly as a response to the macroeconomic systems' mistakes (Emmerson and Hendry, 1998). Survey data and subsequent information function well, especially for now-casting and are well adjusted to measuring business uncertainty (Bachman, 2013).

\subsection{Business cycle survey}

The expected economic development in the near future is a matter of the business cycle survey. It indicates whether economic development is about to change because of economic expansion or recession, which may be translated into significant opportunities for the companies. The EU administers the Joint Harmonised EU Programme of Business and Consumer Surveys, which provides a broad framework for conducting the surveys in the member states.

The surveys are conducted on a monthly basis in the following areas: the manufacturing industry, construction, consumers, retail trade, services and financial services (closer in specification OECD, 2017, pg. 3). The complete results of the Business and Consumer Survey are published two days before the end of each month (OEDC, 2017, pg. 22), which is much earlier than the GDP. The benefit of this data is that it is well accessible, it is not revised and it contains only a few mistakes (Hansson, Jansson and Löf, 2004).

Business survey data is qualitative; it is based on expressing the future in very common answers. The survey is realised through the unambiguous questionnaire, which can be completed by the respondents very quickly (CZSO, 2015). The principle of the business cycle survey is "high frequency, timeliness and continuous harmonization" (OEDC, 2017, 
pg. 2). Various composite indicators are built on the basis of the business survey, and they provide essential information for short-term forecasting and economic surveillance.

\subsection{Reference period in mechanical engineering in the Czech Republic}

We aim to determine the level of agreement between the business survey data from the Czech Republic (CR) and the consequent economy development in CR. The reference period is $2003-2017$. In respect to the significant occurrences and the premise of those in different phases of the business cycle, the reliability of prediction varies (Karel and Hebák, 2018). The analysed time period was divided into 5 sections: 2003 - 2004, 2005 $-2008,2009-2010,2011-2010$ a $2013-2017$ as illustrated in table 1.

Table 1: Time periods analysed

\begin{tabular}{|l|l|}
\hline Time period & Characteristics \\
\hline After 2000 & Moderate irregular growth \\
\hline $2003-2004$ & Moderate growth, 2004 CZ enters EU \\
\hline $2005-2008$ & Economic growth \\
\hline $2009-2010$ & Economic downturn due to the financial crises, 2010 slight recovery \\
\hline $2011-2012$ & Downturn, potential deflation, 2012 Interest rates almost 0 \\
\hline $2013-2017$ & Economic growth, Fixed Exchange rate CZK/Euro \\
\hline
\end{tabular}

Source: SST, CNB

Figure 1: Gross Domestic Product and Manufacturing in Czech Republic (2003 - 2017)

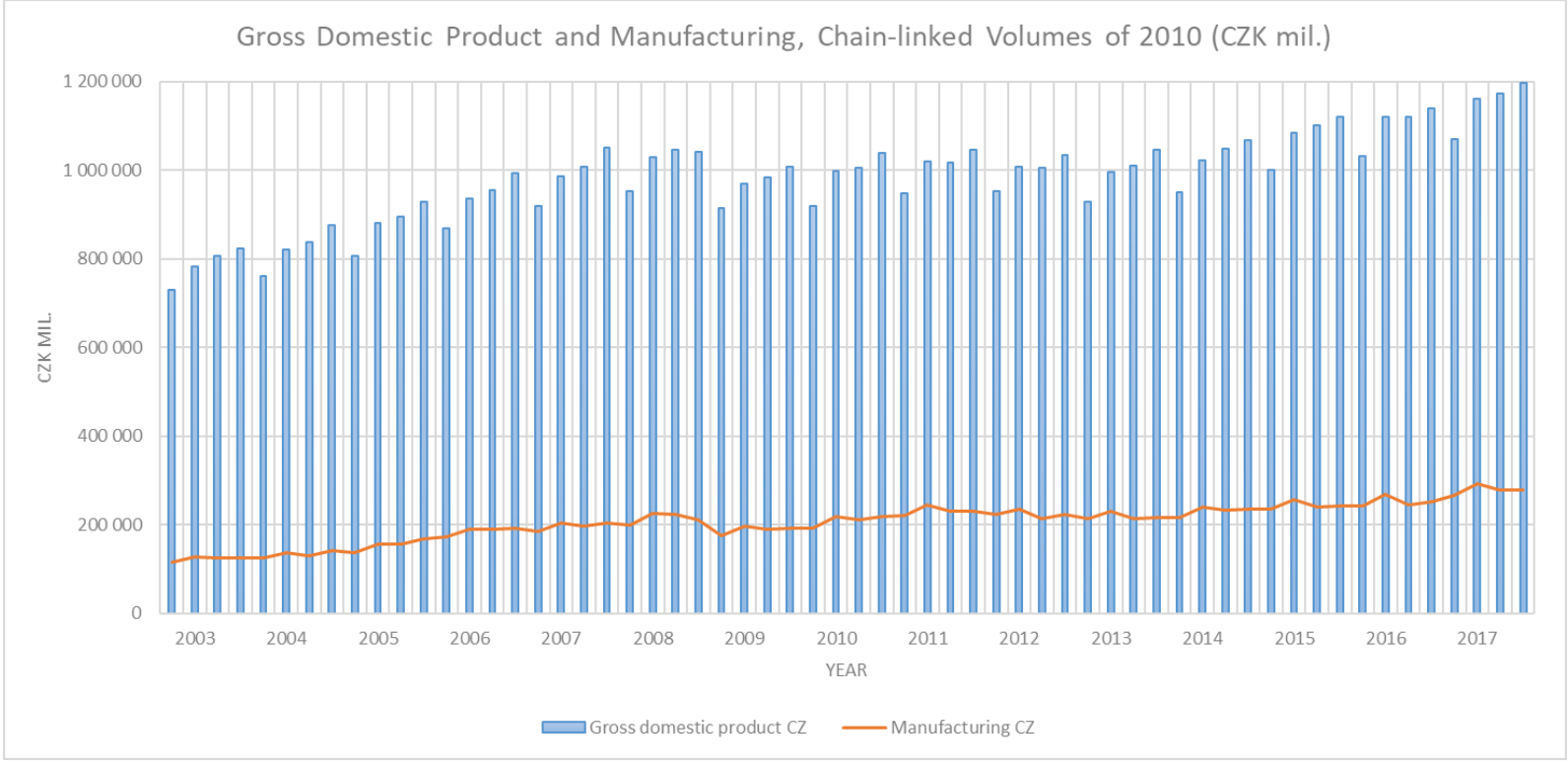

Source: CZSO Resources of Gross Domestic Product, Current Prices 
For the mechanical engineering business, the reference period was quite complex for either economic changes and also for great structural changes in the branch. Looking for new markets and investing in development and innovation was inevitable.

\subsection{The problem}

A considerable number of authors have worked on research on how to adjust the prediction models to provide the most accurate prediction of future economic development. Those models are usually complex and comprise many entering parameters of which some must be estimated. From the literature review it is obvious that simplicity and simple models are evidently desirable. It is the motivation to return to the simplest one, the data directly obtained from the business survey respondents. The paper's objective is to find out how well the industry assessment of order-book levels prediction matches with the subsequent specific economy performance indicators. Those indicators represent three levels of industry performance: gross domestic product of Czech Republic (GDP) as the general economic performance, gross domestic product of Czech Republic, manufacturing industry (GDP NACE C) to which the industry assessment of order-book levels prediction is bound and new industrial orders in mechanical engineering as a subcategory of GDP NACE C. The follow-up question is whether the level of reliability is different with respect to the time period tied to various phases of the business cycle.

\section{Data}

The principle of the analyzed model is that the prediction is confronted by the performance indicator of the selected segment of the economy. The prediction data chosen was a business survey indicator Assessment of order-book levels (AOBL), which refers to the Czech manufacturing industry. It is formulated as a balance of a difference between percentage of positive and negative predictions, while the stagnation share does not enter the balance.

Performance indicator data are supposed to illustrate the economic performance from top to bottom. The reliability will be demonstrated regarding to various economic levels. They are: GDP CR, GDP NACE C CR for the Czech manufacturing industry, which is the reference indicator for the prediction of $A O B L$ and New industrial orders (NIO) NACE 28 as a specific sector of a Czech manufacturing industry. NACE 28 is the nomenclature of "Manufacture of machinery and equipment n.e.c."

The data used in analysis are not revised and not seasonally adjusted. The reason for choosing this type of indicator is that they are quickly accessible and data bias is avoided as the resulting indicator is always influenced by any data treatment before the analysis itself (Erkel-Rousse and Minodier, 2009). 
The data series begins in January 2003 in accordance with the availability of the indicator Assessment of order-book levels for the Czech Republic; in the form of non-seasonally adjusted data the series begins in 2003. The nominal sample size for the Czech industry per survey is 1000 respondents.

The data used for analysis are available in the database of the Czech Statistical Office (CZSO). This resource is chosen for its direct accessibility for the Czech companies. The following table shows the variables analyzed (in our interest).

Table 2: List of variables

\begin{tabular}{|l|l|l|l|}
\hline Variable & Abrev. & Periodicity & Characteristic \\
\hline $\begin{array}{l}\text { Assessment of Order-Book } \\
\text { Levels }\end{array}$ & AOBL & Monthly & $\begin{array}{l}\text { Balances, seasonally not adjusted } \\
\text { (SNA) }\end{array}$ \\
\hline Gross Domestic Product & GDP & Quarterly & $\begin{array}{l}\text { Resources of Gross Domestic Product, } \\
\text { Chain-linked Volumes of 2010, SNA }\end{array}$ \\
\hline $\begin{array}{l}\text { Gross Domestic Product } \\
\text { manufacturing (NACE C) }\end{array}$ & $\begin{array}{l}\text { GDP } \\
\text { NACE C }\end{array}$ & Quarterly & $\begin{array}{l}\text { Resources of Gross Domestic Product, } \\
\text { Chain-linked Volumes of 2010, SNA }\end{array}$ \\
\hline $\begin{array}{l}\text { New Industrial Orders NACE } \\
28 \text { (Manufacture of machinery } \\
\text { and equipment n.e.C.) }\end{array}$ & NIO & Monthly & $\begin{array}{l}\text { Base indices (current prices), (average } \\
\text { month of 2015 =100), SNA }\end{array}$ \\
\hline
\end{tabular}

Source: CZSO, 2018, (Resources of Gross Domestic Product, Business Cycle surveys, New Industrial Orders)

\section{Methods}

The basic model is that the prediction is compared to the performance indicator in a specific economic segment. Firstly, the time aspect should be considered as the predictions are concluded from the past with the effect in the future. The selected business survey indicator relates to the development of the next three months, so that the performance indicator lags by 3 months (CZSO, 2015).

As the dependent variable the Assessment of order-book level for the Czech manufacturing industry was chosen. The indicator is created from the answers to the following questions: Do you consider your current overall order books to be...? The answers offered are: above normal/normal for the season/not sufficient. The balance is aggregated on the difference between the percentages of respondents giving positive and negative replies (OECD, 2017).

The independent variables are the performance indicators of the manufacturing industry, namely: GDP CZ and GDP NACE and as a performance indicator of mechanical engineering there are the new industrial orders NACE 28. 


\subsection{Time lags/periods}

Generally, two types of time period are dealt with - the current period (independent variable) $T$ and the previous period (dependent variable) $T-1$. Two frequencies were taken into account - quarters $Q$ and months $M$. Indicators for quarter series are adjusted as listed in table 3.

Quarters were used for testing the GDP and GDP NACE C model, $Q$ for the current quarter (current period) and $Q-1$ for the previous quarter (previous period). Assessment of order-book level balances is a monthly indicator and the subseries is set as M1, M2, M3 for each month in a quarter.

In quarterly models the monthly series of assessment of order-book level balances were adjusted (see table 3). In two models the AOBL was "bridged" (Angelini et al., 2011) in 1.1 and 1.2 in a way that the differences of M3 predictions were counted. For 1.1 the opposite development of M1 - M3 (rise and fall) was considered, and for 1.2 only the differences were considered. For indicators 1.3, 1.4 and 1.5 the AOBL balances of individual months $(M 1, M 2, M 3)$ of the previous quarter $(Q-1)$ were used.

GDP a GDP NACE C are quarterly data. The data source is from the Resources of Gross Domestic Product, Chain-linked Volumes of 2010 (CZK mil.). It was transformed into the percentage balance of a quarterly change $Q$ to $Q-1$.

Table 3: Indicators adjustment for quarter series

\begin{tabular}{|c|c|c|}
\hline Indicator & Type & Method \\
\hline$A O B L$ for $Q(A)$ & 1.1 & $\begin{array}{l}M 3(Q-1)-M 3(Q-2) \text {; if } M 1, M 2, M 3 \text { increases and decreases } \\
\text { during the } Q \text {, the result is } 0 \text { (neutral), tolerance } 0,5 \%\end{array}$ \\
\hline AOBL for $Q(B)$ & 1.2 & $M 3(Q-1)-M 3(Q-2)$, under $1 \%$ result is 0 (neutral) \\
\hline AOBL M1 & 1.3 & $\mathrm{M} 1(\mathrm{~T}-1)$ \\
\hline AOBL M2 & 1.4 & $\mathrm{M} 2(\mathrm{~T}-1)$ \\
\hline AOBL M3 & 1.5 & $\mathrm{M} 3(\mathrm{~T}-1)$ \\
\hline GDP change & 1.6 & $1-(\mathrm{GDP}(\mathrm{T})$ / GDP $(\mathrm{T}-1))$, tolerance $0,5 \%$ \\
\hline GDP NACE C change & 1.7 & 1 - (GDP NACE C (T) / GDP NACE C (T-1)), tolerance 0,5\% \\
\hline
\end{tabular}

Source: Author

The month-frequency series of both indicators were used for testing AOBL with the new industrial orders. The months are $M$ for the current month (current period) and $M-1$ for the previous month (previous period). The AOBL balances are not adjusted. Indicators for monthly series are adjusted as listed in table 4.

To be able define the matches we also intend to discover how the time interval would change the result. Three types of NIO were used; $m+1$ is NIO of the month directly following the prediction, $\mathrm{m}+2$ is a cumulative outcome of $\mathrm{NIO}$ of the two months 
following the prediction, and $\mathrm{m}+3$ is a cumulative outcome of $\mathrm{NIO}$ of the three months following the prediction.

Table 4: Indicators adjustment for monthly series

\begin{tabular}{|l|l|l|}
\hline Indicator & Type & Method \\
\hline AOBL & 2.1 & M \\
\hline NIO m1 & 2.2 & NIO M1 \\
\hline NIO m2 & 2.3 & NIO (M1) + NIO (M2) \\
\hline NIO m3 & 2.4 & NIO (M1) + NIO (M2) + NIO (M3) \\
\hline
\end{tabular}

Source: Author

All adjustments resulted in balances that represent a specific increase or decrease. All indicators entering the models were transformed into simple signs like those at traffic lights: Increase +; Decrease -; Neutral prediction 0 .

The neutral prediction comprises the increase or decrease of up to $1 \%$.

\subsection{Relations}

The indicators entering the relations tested are showed in table 5.

Table 5: Variable pairs analysed

\begin{tabular}{|l|l|l|l|l|}
\hline Type & Dependent variable & Period & Independent variable & Period \\
\hline 1.1 .1 & AOBL $(\mathrm{A})$ & $\mathrm{Q}-1$ & GDP change & $\mathrm{Q}$ \\
\hline 1.1 .2 & AOBL $(\mathrm{A})$ & $\mathrm{Q}-1$ & GDP NACE C change & $\mathrm{Q}$ \\
\hline 1.2 .1 & AOBL $(\mathrm{B})$ & $\mathrm{Q}-1$ & GDP change & $\mathrm{Q}$ \\
\hline 1.2 .2 & AOBL $(\mathrm{B})$ & $\mathrm{Q}-1$ & GDP NACE C change & $\mathrm{Q}$ \\
\hline 1.3 .1 & AOBL M1 & $\mathrm{Q}-1$ & GDP change & $\mathrm{Q}$ \\
\hline 1.3 .2 & AOBL M1 & $\mathrm{Q}-1$ & GDP NACE C change & $\mathrm{Q}$ \\
\hline 1.4 .1 & AOBL M2 & $\mathrm{Q}-1$ & GDP change & $\mathrm{Q}$ \\
\hline 1.4 .2 & AOBL M2 & $\mathrm{Q}-1$ & GDP NACE C change & $\mathrm{Q}$ \\
\hline 1.5 .1 & AOBL M3 & $\mathrm{Q}-1$ & GDP change & $\mathrm{Q}$ \\
\hline 1.5 .2 & AOBL M3 & $\mathrm{Q}-1$ & GDP NACE C change & $\mathrm{Q}$ \\
\hline 2.2 .1 & AOBL & $\mathrm{M}$ & NIO m1 & $\mathrm{M}+1$ \\
\hline 2.3 .1 & AOBL & $\mathrm{M}$ & NIO m2 & $\mathrm{M}+2$ \\
\hline 2.4 .1 & AOBL & $\mathrm{M}$ & NIO m3 & $\mathrm{M}+3$ \\
\hline
\end{tabular}

Source: Author 
The analyses of indicator pairs from table 5 inhered in evaluating the match between the tendencies of increase, decrease and stagnation. The indicators were put together as follows: the dependent indicator in time $T-1$ to the independent indicator in time $T$. The level of match was formulated in three grades: match, close match and mismatch. The method is visualized in table 6 .

Table 6: Variables' match

\begin{tabular}{|l|l|l|l|}
\hline Variable & Dependent + & Dependent - & Dependent 0 \\
\hline Independent + & Match $(+1)$ & Mismatch $(-1)$ & Close match $(0)$ \\
\hline Independent - & Mismatch $(-1)$ & Match $(+1)$ & Close match $(0)$ \\
\hline Independent 0 & Close match $(0)$ & Close match $(0)$ & Match $(+1)$ \\
\hline
\end{tabular}

Source: Author

\section{Results}

The reliability of AOBL was tested towards the GDP, GDP NACE C and NIO results. The model shed light on whether it was possible to rely on the prediction trend (increase, decrease, stagnation). The numbers of matches/close matches/mismatches were calculated into shares (total 1) for particular models because the time periods covered provided various measurements.

Table 7: Summarized rates for all models during all time periods $(2003-2017)$

\begin{tabular}{|l|l|l|l|l|}
\hline $\begin{array}{l}\text { Model } \\
\text { (all periods 2003 - 2017) }\end{array}$ & \multicolumn{1}{l|}{ Type } & Close Match & Mismatch \\
\hline GDP vs AOBL (A) & 1.1 .1 & 0,25 & 0,56 & 0,19 \\
\hline GDP vs AOBL (B) & 1.2 .1 & 0,34 & 0,34 & 0,32 \\
\hline GDP vs AOBL M1 & 1.3 .1 & 0,42 & 0,18 & 0,40 \\
\hline GDP vs AOBL M2 & 1.4 .1 & 0,37 & 0,17 & 0,47 \\
\hline GDP vs AOBL M3 & 1.5 .1 & 0,40 & 0,15 & 0,45 \\
\hline GDP C vs AOBL (A) & 1.1 .2 & 0,34 & 0,51 & 0,15 \\
\hline GDP C vs AOBL (B) & 1.2 .2 & 0,37 & 0,37 & 0,25 \\
\hline GDP C vs AOBL M1 & 1.3 .2 & 0,33 & 0,20 & 0,47 \\
\hline GDP C vs AOBL M2 & 1.4 .2 & 0,38 & 0,20 & 0,42 \\
\hline GDP C vs AOBL M3 & 1.5 .2 & 0,40 & 0,18 & 0,42 \\
\hline NIO m1 vs AOBL & 2.2 .1 & 0,43 & 0,18 & 0,39 \\
\hline NIO m2 vs AOBL & 2.3 .1 & 0,45 & 0,14 & 0,41 \\
\hline NIO m3 vs AOBL & 2.4 .1 & 0,38 & 0,19 & 0,43 \\
\hline
\end{tabular}

Source: Author's computations 
Different methods of $A O B L$ adjustment have been reflected in the clarity of the results (table 7). In bridging cases (see table 3, type 1.1 and 1.2) the result "close match" is above average (up to $50 \%$ ), which means that the variables vary by one degree (one is stagnant and the other is increasing or decreasing). Only during the economic downturn in 2009 - 2010 were the close matches almost eliminated. In cases of comparing the monthly AOBL balances for individual months (M1, M2, M3) to the GDP and GDP NACE $C$ (relations 1.3.1 - 1.5.2) the number of ambiguous matches decreases to $20 \%$. The match level of AOBL and GDP NACE $C$ is the highest with $M+3$ period, which is the last month before the quarter in which industry performance is measured.

When evaluating the reliability of forecasts against NIO the matches were higher than for GDP NACE C. The highest match resulted for AOBL $M+2(45 \%)$, then $M+1(43 \%), M$ $+3(38 \%)$.

When considering the time period, the reliability of predictions varies according to the phase of the economic cycle (table 8 ). Overall results show that the best predictions were in periods of clear growth $2005-2008,44 \%$ (GDP NACE C) and $51 \%$ (NIO) clear matches. The worst predictions were in periods of economic downturn $2009-2010,48 \%$ (GDP NACE C) and $56 \%$ (NIO) clear mismatches. The last growth period (2015 - 2017) also shows a relatively high match ( $43 \%$ match).

Table 8: Summarized rates for various models according to time periods

\begin{tabular}{|l|c|c|c|c|c|c|c|c|c|}
\hline Model & \multicolumn{4}{|l|}{ GDP vs AO } & \multicolumn{3}{l|}{ GDP C vs AOBL } & \multicolumn{3}{l|}{ NIO vs AOBL } \\
\hline $\begin{array}{l}\text { Time } \\
\text { period }\end{array}$ & Match & $\begin{array}{l}\text { Close } \\
\text { Match }\end{array}$ & $\begin{array}{l}\text { Mis- } \\
\text { match }\end{array}$ & Match & $\begin{array}{l}\text { Close } \\
\text { Match }\end{array}$ & $\begin{array}{l}\text { Mis- } \\
\text { match }\end{array}$ & Match & $\begin{array}{l}\text { Close } \\
\text { Match }\end{array}$ & $\begin{array}{l}\text { Mis- } \\
\text { match }\end{array}$ \\
\hline $\mathbf{0 3 - 0 4}$ & 0,21 & 0,30 & 0,49 & 0,39 & 0,33 & 0,28 & 0,33 & 0,31 & 0,36 \\
\hline $\mathbf{0 5 - 0 8}$ & 0,46 & 0,29 & 0,25 & 0,44 & 0,28 & 0,29 & 0,51 & 0,13 & 0,37 \\
\hline $\mathbf{0 9 - 1 0}$ & 0,33 & 0,13 & 0,55 & 0,40 & 0,13 & 0,48 & 0,39 & 0,06 & 0,56 \\
\hline $\mathbf{1 1 - 1 4}$ & 0,36 & 0,29 & 0,35 & 0,30 & 0,33 & 0,38 & 0,39 & 0,17 & 0,44 \\
\hline $\mathbf{1 5 - 1 7}$ & 0,32 & 0,35 & 0,33 & 0,32 & 0,37 & 0,32 & 0,43 & 0,23 & 0,34 \\
\hline $\mathbf{0 3 - 1 7}$ & 0,36 & 0,28 & 0,37 & 0,37 & 0,29 & 0,34 & 0,42 & 0,17 & 0,41 \\
\hline
\end{tabular}

Source: Author's computations

The clearest results are provided by the relation AOBL vs NIO.

\section{Discussion}

The presented research aimed to verify whether untreated information obtained from the business cycle survey provides reliable information on future development in the industry. This reliability varies on the basis of the method applied and on the basis of the time 
periods that were chosen according to the course of economic cycle in the Czech economy.

The research indicates that in times of economic upturn the future development predictions correspond to real performance up to $51 \%$. In periods of economic downturn, the level of disagreement is maximized up to $58 \%$. This interesting finding shows the possibility of a certain subjective influence in creation of the prediction a deserves further detailed research. Hansson Jansson and Löf (2004) and Erkel-Rousse and Minodier (2009) state that simple models often work as well as the more complex ones. The research presented in this article confirms these findings, however, it depends very much on the chosen variables and procedures.

\section{Conclusion}

An expert estimate of the future development of the field is invaluable. The B2B purchase decision uncertainty affects the quality of purchase practice, and it affects complex business expenses. Short-term indicators of the development of certain parts of the economy unveil a lot. They anticipate the expected trends and the atmosphere in the business environment (directly from those who operate in the field), which in time are reflected in real changes in the market. The literature review has indicated the need for simple prediction models, so the subject matter of the paper is the basic indicator of data reliability.

The objective of the paper was to determine the reliability of predictions of the demand development in a subsequent confrontation with reality, so we ask what the level of compliance of the assessment of order-book levels forecast with the subsequent development of selected performance indicators is, taking into account the time period representing a certain phase of the business cycle. The business cycle data, which come directly from the business cycle survey and are not treated, were compared to real performance on three levels (GDP, GDP NACE C, New industrial orders NACE 28) within a certain time period.

Predictions vary depending on the stage of the business cycle. The best predictions were in $2005-2008,44 \%$ (GDP NACE C) and $51 \%$ (NIO) of clear matches. Worst predictions were made during the economic downturn $2009-2010$, 48\% (GDP NACE C), and 56\% (NIO) of clear disagreements. In the last period of $2015-2017$ growth, matches are relatively high for NIO $43 \%$. The various methods of the assessment of order-book level treatment have been reflected in the unambiguity of the results. The highest match was issued for assessment of order-book level $M+2$, then $M+1, M+3$.

It can be stated that the reality that follows the prediction largely corresponds to the prediction, but this rate varies in relation to the stage of economic cycle. The most reliable are the predictions of the period of clear growth, and the least reliable are the periods of significant decline. In the mechanical engineering field, the forecasts are quite reliable 
and can be recommended to managers as a supportive or complementary factor that they should include in their decision-making.

The business cycle research is standardized worldwide so that the research results are a matter of international significance. This research represents the starting point for wider research of the reliability of basic data from the business cycle survey. Another data series related to the business trend will be tested. The real usage and trust of managers in prediction indicators will be addressed by further research.

\section{Acknowledgement}

Author is thankful to the Internal Grant Agency of FaME TBU No. IGA/FaME/2018/001 "Leading indicators in the buying behavior of companies in B2B markets" for financial support to carry out this research.

\section{References}

ANGELINI, E., CAMBA-MENDEZ, G., GIANNONE, D., REICHLIN, L., RÜNSTLER G. (2011). Short-term forecasts of euro area GDP growth. Econometrics Journal, 14(1), C25 - C44. DOI: 10.1111/j.1368423X.2010.00328.x.

BACHMANN, R., ELSTNER, S., SIMS, E.R. (2013). Uncertainty and economic activity: Evidence from business survey data. American Economic Journal: Macroeconomics [online], 5(2), 217 - 249. DOI: 10.1257/mac.5.2.217.

BACKHAUS K., BRÖKER O., BRÜNE P., GAUSLING, P. (2013). Digitale Medien in B2BBeschaffungsprozessen - eine explorative Untersuchung, Arbeitspapiere, Institut für Anlagen und Systemtechnologien, Westfälische Wilhelms-Universität Münster, No. 52. Retrieved from: https://www.econstor.eu/bitstream/10419/80715/3/Digitale_Medien_in_B2BBeschaffungsprozessen.pdf

BOIVIN, Jean, NG, Serena. (2005). Understanding and Comparing Factor-Based Forecasts. International Journal of Central Banking, vol. 1(3), 2005, December. Retrieved from: http://www.ijcb.org/journal/ijcb05q4a4.htm.

BROWN, B. P., ZABLAH, A: R., BELLENGER, D. N., JOHNSTON, W. J. (2011). When do B2B brands influence the decision making of organizational buyers? An examination of the relationship between purchase risk and brand sensitivity. International Journal of Research in Marketing, 28(3), pp. 194204. Retrieved from: https://doi.org/10.1016/j.ijresmar.2011.03.004.

CLARK, Todd E., WEST, Kenneth D. (2007). Approximately normal tests for equal predictive accuracy in nested models. Journal of Econometrics [online], 138(1), 291-311. DOI: 10.1016/j.jeconom.2006.05.023.

Czech National Bank (CNB). (2018). Ekonomický vývoj na území České republiky [online]. Retrieved from: http://www.historie.cnb.cz/cs/menova_politika/prurezova_temata_menova_politika/1_ekonomicky_vy voj_na_uzemi_ceske_republiky.html

Czech Statisical Office (CZSO). (2015, March 13). Business cycle surveys - Methodology [online]. Retrieved from: https://www.czso.cz/csu/czso/business_cycle_surveys

Czech Statisical Office (CZSO). (2018, June 29). Resources of Gross Domestic Product, Current Prices [online]. Retrieved from: https://www.czso.cz/csu/czso/hdp_cr 
GIANCARLO, Bruno, CLAUDIO, Lupi. (2003). Forecasting Euro-Area Industrial Production Using (Mostly) Business Surveys Data. ISAE Working Papers 33, ISTAT - Italian National Institute of Statistics (Rome, ITALY). Retriever from: http://ec.europa.eu/economy_finance/db_indicators/surveys/documents/working_papers/wp2003_03 _isae_33.pdf

ERKEL-ROUSSE, Hélène, MINODIER, Christelle. (2009). Do business tendency surveys in industry and services help in forecasting GDP growth? A real-time analysis on French data. Institut National de la Statistique et des Etudes Economiques INSEE - DESEVersion: G2009/03. Retrieved from: https://www.researchgate.net/publication/289975896_Do_business_surveys_in_industry_and_servic es_help_in_forecasting_GDP_growth_A_real-time_analysis_on_French_data

FIALOVÁ, H. Mezinárodní obchod I: Cíle a nástroje konjunkturní analýzy. Brno: VUT, 2000. Česká republika. ISBN 80-214-1594-0.

GRÖßLER, Andreas, Enzo BIVONA a Fuzhuang LI. (2015). Evaluation of asset replacement strategies considering economic cycles: lessons from the machinery rental business. International Journal of Modelling in Operations Management [online], 5(1), 52-71. ISSN 20424094. Retrieved from: https://doi.org/10.1504/IJMOM.2015.069241

HANSSON, Jesper, Per JANSSON a Mårten LÖF. (2005). Business survey data: Do they help in forecasting GDP growth? International Journal of Forecasting [online], 21(2), 377-389. DOI: 10.1016/j.ijforecast.2004.11.003. ISSN 01692070.

KAREL, Tomáš, HEBÁK, Petr. (2018). Forecasting Czech GDP using Bayesian dynamic model averaging. International Journal of Economic Sciences, Vol. VII(1), pp. 65-81. DOI: 10.20472/ES.2018.7.1.004

LILLIEN, G. L. (2016). The B2B Knowledge Gap. International Journal of Research in Marketing, vol. 33(3), pp 543-556. ISSN: 0167-8116. Retrieved from: https://doi.org/10.1016/j.jiresmar.2016.01.003

LIN, Yi-Chen a Tai-Hsin HUANG. (2012). Creative destruction over the business cycle: a stochastic frontier analysis. Journal of Productivity Analysis [online], 38(3), 285 [cit. 2016-05-25]. ISSN 0895562X. Retrieved from: https://doi.org/10.1007/s11123-012-0273-3

LYNCH, J., L. DE CHERNATONY. (2004). The power of emotion: Brand communication in business-tobusiness markets. Brand Management, 11(5), pp. 403-419]. ISSN 1479-1803, Retrieved from: https://doi.org/10.1057/palgrave.bm.2540185

OECD. (2017). The Joint Harmonised EU Programme of Business and Consumer Surveys, User Guide. Retrieved from: https://ec.europa.eu/info/files/user-guide-joint-harmonised-eu-programme-businessand-consumer-surveys_en

POVOLNÁ, L.: Marketing Communications on B2B Markets. DOKBAT 2017 Conference Proceedings, Zlín, 26. 4. 2017, UTB. Retrieved from: http://dokbat.utb.cz/wp-content/uploads/DOKBAT2017.pdf

SRINIVASAN, R., G. L. LILIEN, S. SRIDHAR. (2011). Should Firms Spend More on Research and Development and Advertising During Recessions? Journal of Marketing, vol 75(3), pp. 49-65. ISSN: 0022-2429. DOI: $10.1509 / j \mathrm{mkg} .75 .3 .49$

SST - Association of Engineering Technology. Report on the Machine Tools Branch in the Czech Republic in 2016. [online] (2017). Prague. Retrieved from: https://www.sst.cz/images/VZ_SST_2017_TISK_LASER.pdf

WEBSTER, F. E. Jr., WIND, Y. (1972). A General Model for Understanding Organizational Buying Behavior. Journal of Marketing, vol. 30, pp. 220-233. ISSN: 0022-2429. Retrieved from: https://archive.ama.org/archive/ResourceLibrary/MarketingManagement/documents/9604142669.pdf 
WIERSEMA, F. (2013). The B2B Agenda: The current state of B2B marketing and a look ahead. Industrial Marketing Management, vol 42(4), 470-488. ISSN: 0019-8501. Retrieved from: https://www.researchgate.net/publication/256720262_The_B2B_Agenda_The_current_state_of_B2B _marketing_and_a_look_ahead

WIND, Y., THOMAS, R. J. (2010). Organizational buying in an interdependent Word. Journal of Global Academy of Marketing Science, 20(2). 110-122. DOI: 10.1080/12297119.2010.9730184 